\title{
Indentation Model Using Gravity Anomaly and Anisotropy of Magnetic Susceptibility: Consequences on Nappe Rotations in the Chélif Basin, Algeria
}

\author{
Tahar Aifa ${ }^{*}, 1$ and Mouloud Idres ${ }^{2}$ \\ ${ }^{I}$ Géosciences-Rennes, CNRS UMR6118, Université de Rennes 1, Bat.15, Campus de Beaulieu, 35042 Rennes Cedex, \\ France \\ ${ }^{2}$ Département de Géophysique, USTHB, BP32, Bab-Ezzouar El-Alia, 16111 Algiers, Algeria
}

\begin{abstract}
An anisotropy of magnetic susceptibility (AMS) study was conducted on 57 specimens of Tortonian to Pliocene sandstones and completed by an interpretation of the gravity anomaly map of the Chélif Basin (Algeria) in order to confirm the indentation model of the basement and its consequences on the rotations of the nappes.

Inversion of residual gravity data, obtained from 428 measurements, using the Parker-Oldenburg algorithm helped to investigate the undulation of the basement and to evidence the main geological features. Gravity modeling along five NW-SE and SW-NE oriented cross-sections did not allow us to detect any vertical offset of T1 and T2 evidenced contacts, but confirms the $\mathrm{T} 1$ dextral and $\mathrm{T} 2$ sinistral shears.

Rock magnetic investigations show that the corrected anisotropy degree P' ranges from 1.03 to 1.38 , except for the ElAbadia (EA) site where it reaches 1.82. The main magnetic fabric is either oblate or prolate, except for two sites (OS and $\mathrm{OU})$ where the oblate shape prevails. The main magnetic carrier is likely magnetite; other minerals such as goethite and sulphides were evidenced through transformation into magnetite after heating.

Due to successive remagnetizations, the rotation amounts deduced from AMS measurements are higher than those deduced from remanence and follow the same direction. The Oum-Drou (OU) site, facing the indenter, did not rotate significantly $\left(\sim 2^{\circ}\right)$ which is in agreement with both magnetic lineation and remanent magnetization and consistent with the indentation model. West of the T1 dextral strike-slip fault, evidenced by gravity, a clockwise rotation of $\sim 25^{\circ}$ is recorded. Far to the east, the rotation value decreases as far as the Mdjaïa (MD) site, where a clockwise rotation of $\sim 10^{\circ}$ is recorded.
\end{abstract}

Finally, the deepened compressional basin corresponds with the direction of shortening deduced from neotectonics, gravity and AMS.

Keywords: Gravity, Parker-Oldenburg inversion, AMS, modeling, Rotation, Chélif Basin.

\section{INTRODUCTION}

The Chélif Basin in Algeria is an intra-montane basin of the Tellian chain, elongated in an EW direction (Fig. 1). It is constituted of Mio- to Pliocene and Quaternary terranes on a Cretaceous basement, and mainly characterized by its variable topography. Its structural development resulted from extensional movements contemporaneous with the opening of the Mediterranean Sea [1,2]. Subsequently, compressional movements have begun to develop at least since the middle Pliocene (3 Ma) according to palaeomagnetic arguments [3], during the lower Pliocene (5 Ma) according to neotectonic arguments [2] and this continued till the Quaternary. As remagnetization is a middle Pliocene phenomenon, it is attributed to the compressional stress field between the upper Tortonian and middle Pliocene [3]. This agrees with the neotectonic measurements which

*Address correspondence to this author at the Géosciences-Rennes, CNRS UMR6118, Université de Rennes 1, Bat.15, Campus de Beaulieu, 35042 Rennes Cedex, France; Tel: +33 (0)2 232367 85; Fax: +33 (0)2 232360 97; E-mail: tahar.aifa@univ-rennes1.fr show a change, i.e. a shortening from NNE-SSW (during lower Pliocene) to NNW-SSE (during Holocene) [4]. According to neotectonic data, a deformation band of 50 to $100 \mathrm{~km}$ was found [5]. It is located within the GoringeAlboran-Atlas tellian zone (GALTEL), comprising the Chélif Basin. This band is affected by deformations resulting from the association of dextral movements of the AçoresGibraltar transform and the African-Eurasian convergence [6].

In order to characterize the morphology of the basement beneath the Chélif Basin, we drew up a Bouguer anomaly map, using 428 gravity measurements. The interpretation of the residual map, obtained by subtracting a regional gradient from the Bouguer anomaly, confirmed the NNW-SSE compression trend and evidenced two major shear fractures, dextral to the east (T1) and sinistral to the west (T2). A model of basement relief indentation of the basin was proposed to explain the emplacement of such fractures. As the Chélif Basin is a compressional E-W basin, the shortenings are mainly N-S oriented. This tectonic compressional regime led to rotations of Mio-Pliocene 


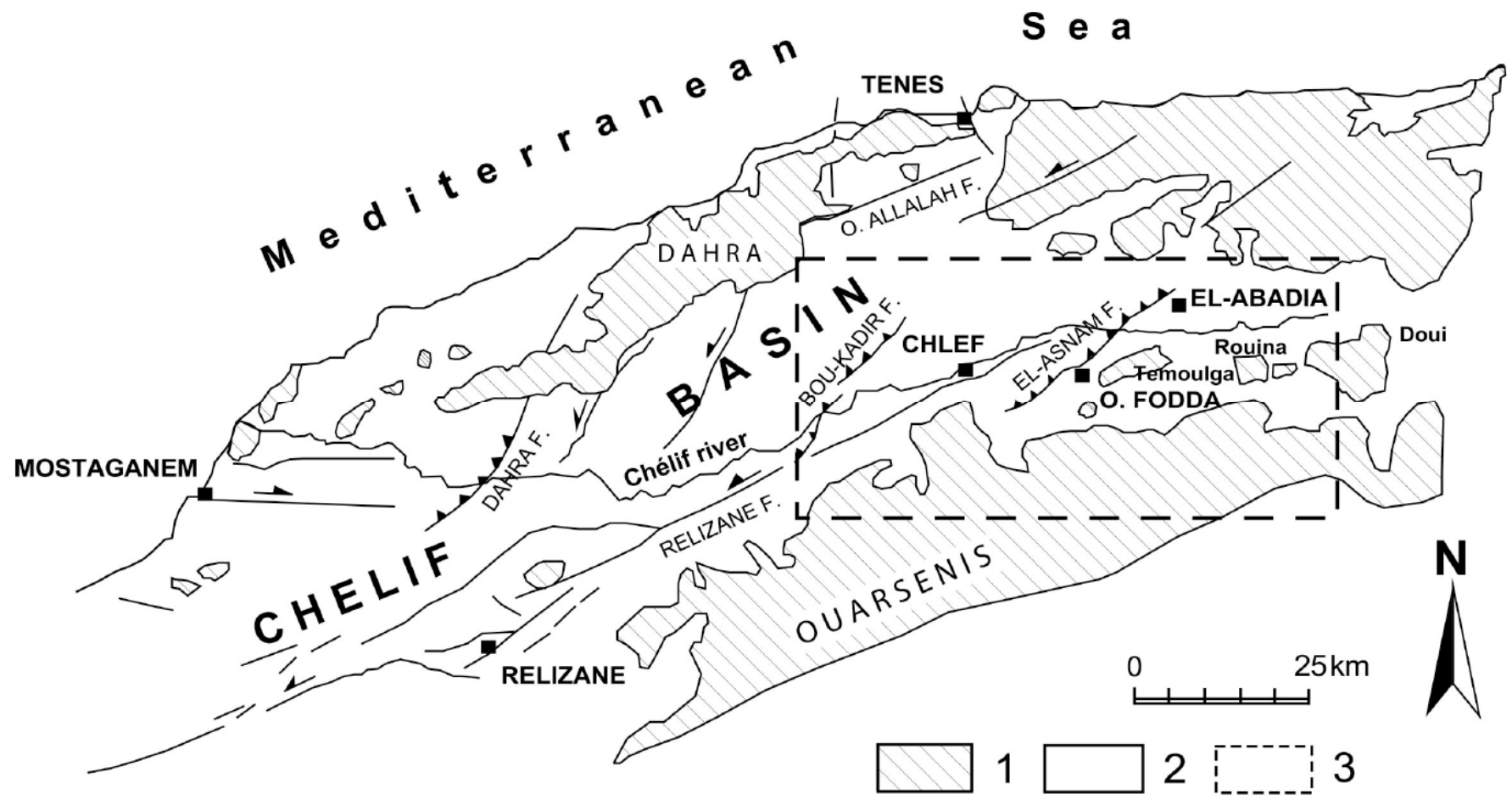

Fig. (1). Geologic map of the Chélif Basin [2] and location of the study area. 1: prior to Neogene basement, 2: Neogene basin, 3: study area.

sediments, evidenced by palaeomagnetic data [3]. The values of the rotations decrease towards the east far from the indentation area. Experimental modeling [7] predicts in this case (to the west) clockwise rotations of blocks or nappes around a vertical axis. As clockwise rotations of blocks of $10^{\circ}$ to $25^{\circ}$ were determined mainly through the computed components of magnetization or remagnetization starting at ca. $3 \mathrm{Ma}$ [3], the aim of this work is to decipher the history of the geotectonic setting in the Chélif Basin, and also to quantify the block rotation values associated with the neotectonism using both the magnetic fabric [8] and the gravity anomaly data to evidence and to confirm such rotations. The measurements of specimens from 5 sites in the Chélif Basin give us information as follows: 1) the total amount of block rotations and 2) the palaeocurrents within this basin, and 3) the estimated age of the compressional event and a better understanding of the indentation mechanism.

\section{GEOLOGICAL SETTING}

Previous studies on the Chélif Basin show that the beginning of its structural evolution occurred during the Tortonian with extensional movements leading to the opening of the Mediterranean Sea [1, 9, 10]. Compressional movements have taken place from the Pliocene onwards [11]. Some relics of the pre-Chélif basement were uplifted and cropped out in the basin as epi-metamorphic massifs of different sizes. They are composed of Palaeozoic and Mesozoic units. Stratigraphic data show that the base of the Palaeozoic units is constituted of a metamorphic basement composed of granodiorites associated with some pegmatites [12]. The metamorphism predates the Alpine phase [12]. A schist series dating from the Silurian or the Devonian lies on top of this basement that is composed of lavas (dacites, andesites and trachyandesites) and tuffs from a volcanic complex. Mesozoic units are composed of Triassic (carbonate facies), Jurassic (limestones and marlylimestones) and Cretaceous (mainly sandstones) formations [12]. These massifs belong to the Maghrebides chain and are characterized by polyphase tectonics, Alpine in age, responsible for folds associated with epizonal-type schistosity and metamorphism [12]. This tectonic phase of folding results from the N-S compressional regime related to the shortening of the African-European plates. The consequences are basement thrusting ( « écaillage ») at depth. From a geological point of view, Kirèche [12] argued that these massifs are autochthonous.

The last seismic event of El-Asnam (10.10.1980), was due to a $\mathrm{N} 130^{\circ}$ shortening of the African-European plates and yielded important tectonic movements that were observed in the field. It occurred at a reactivated sinistral fault trending NE-SW and $40 \mathrm{~km}$ long, with vertical movements reaching locally $\sim 6 \mathrm{~m}$ and horizontal shearing movements higher than $\sim 1 \mathrm{~m}$ and of shortened by $\sim 3 \mathrm{~m}[4$, 13]. $80 \mathrm{~km}$ north of the Chélif Basin, the Chenoua Massif was also subjected to clockwise rotation of blocks which could reach values of $20^{\circ}$ since the Middle Pliocene [14]. These rotations are interpreted in the frame of a N-S indentation model [3].

The Ouled Farès area belongs to the northern margin of the Chélif graben, infilled with Tertiary and Quaternary sediments more than $3 \mathrm{~km}$ thick [15]. The oldest outcrops are Messinian in age [4]. At Ouled Farès, the marine regression during the lower Pliocene is represented by a succession of marine and continental sediments. Most of the shales and sands are poorly consolidated, with rare intercalations of limestones. From field observations we can distinguish: 1) a major unconformity between Pliocene sandstones (lower and upper Pliocene) and sandy-silty 
conglomeratic Quaternary sediments; and 2) two principal directions of folding: $\mathrm{E}-\mathrm{W}$ to $\mathrm{N} 110^{\circ}$, affecting the Pliocene deposits and NE-SW to $\mathrm{N} 070^{\circ}$ affecting the Quaternary deposits [2]. Upper Pliocene sequences include red continental deposits. Upper Pliocene and lower Quaternary sediments are unconformably lying on sediments of different ages. In the Chélif area, E-W and SE-NW structural directions prevail $[4,16]$. The main SW-NE tectonic direction is followed by systems of parallel folds dating from Pliocene-Quaternary. Several units have been described, among them the anticlinal and the flexure of Cinq Palmiers (Fig. 3) [17].

\section{GRAVITY DATA}

A gravity survey within the Chélif Basin was conducted using a Worden gravity-meter combined with altimetric levels. It is composed of 428 stations measured along roads and tracks (Fig. 2). The Bouguer anomaly map was computed according to the IGSN71 system with an error of $\sim 0.3$ mGals. A residual map was obtained by subtracting from the Bouguer anomaly a regional gradient (an inclined plane of $1 \mathrm{mGal} / \mathrm{km}$ decreasing amplitude towards the south). The residual anomaly map (Fig. 2) shows that the Chélif Basin is composed, from west to east, of three units (western, central and eastern). Its main trend is WSW-ENE oriented, in the west, becoming E-W in the centre and eastward. This basin is limited to the south by two uplifts of a Cretaceous basement, on top of which a Jurassic lens (the Temoulga Massif) overlies in the west. The western part of the basin is limited in the north and the south by two gravimetric discontinuities that correspond to the Boukadir fault (BKF) and the Relizane fault (RF) respectively. The eastern part of the Chélif Basin is limited by two other gravimetric discontinuities. The first discontinuity, in the south, consists of two segments $\sim 35 \mathrm{~km}$ long. It would correspond to the El-Asnam fault (EAF). The second gravimetric discontinuity (GD), in the north, could indicate a hidden fault that is not observed on the surface. The interpretation of the residual anomaly map of the Chélif Basin (Fig. 2) suggests two main fractures of NNW-SSE direction, with a dextral component to the east (T1) and a sinistral one to the west (T2). These strike-slip faults are not observed on the surface. They offset the eastern part of the basin to the SSE and its central part is ejected to the NNW
(Fig. 2). The RF, EAF and BKF faults correspond to reverse faults generated through a compressional regime, associated with conjugated faults of $\mathrm{N} 140^{\circ}$ direction, producing block or nappe rotations at the surface. A structural scheme representing the indentation of the basin, through geometric irregularities of the basement is presented in Fig. (3). To better define the geometry of the basement, at various places, we computed a three-dimensional model through the inversion of gravimetric data extracted from the residual anomaly map (Fig. 2). The code used in this study is based on the Parker-Oldenburg algorithm [18]. It requires the knowledge of two parameters, the density contrast between the basement and the sedimentary cover, and the average depth of the interface which separates them. Knowing that the basement is primarily composed of Cretaceous terranes overlain in the east by Jurassic terranes outcropping in the Temoulga Massif, we considered its average density to be $2.4 \mathrm{~g} / \mathrm{cm}^{3}$. The density of the sedimentary cover $\left(2.15 \mathrm{~g} / \mathrm{cm}^{3}\right)$ was selected as the average density of the terranes that comprise it (Tortonian, Messinian, Mio-Pliocene and Quaternary). The contrast of density used in the model is equal to $0.25 \mathrm{~g} / \mathrm{cm}^{3}$. From models computed for various values of average depth, we retained the one corresponding to $2 \mathrm{~km}$ because it is constrained by the minimal depth of the basement on the level of the Temoulga Massif where it outcrops. The model obtained (Fig. 4) shows that the basement located at the south of the study area is composed of two distinct parts:

- $\quad$ The deeper part of the basin, controlled by the RF and BKF faults, is narrowed towards the west. These two faults oriented WSW-ENE are each made up of two segments.

- In the west, the EAF fault could be traced with three segments by fitting the shape of the basin on this level.

The Chélif Basin, being limited to the north and the south by the Dahra and Ouarsenis Massifs (Fig. 1), currently evolves in a compressive mode directed from NNW to SSE, respectively. This obviously explains why the BKF, RF and EAF faults have partly shifted under the indentation pressure of the basement (Fig. 4). As the previous model does not take into account the composition of the basement and the

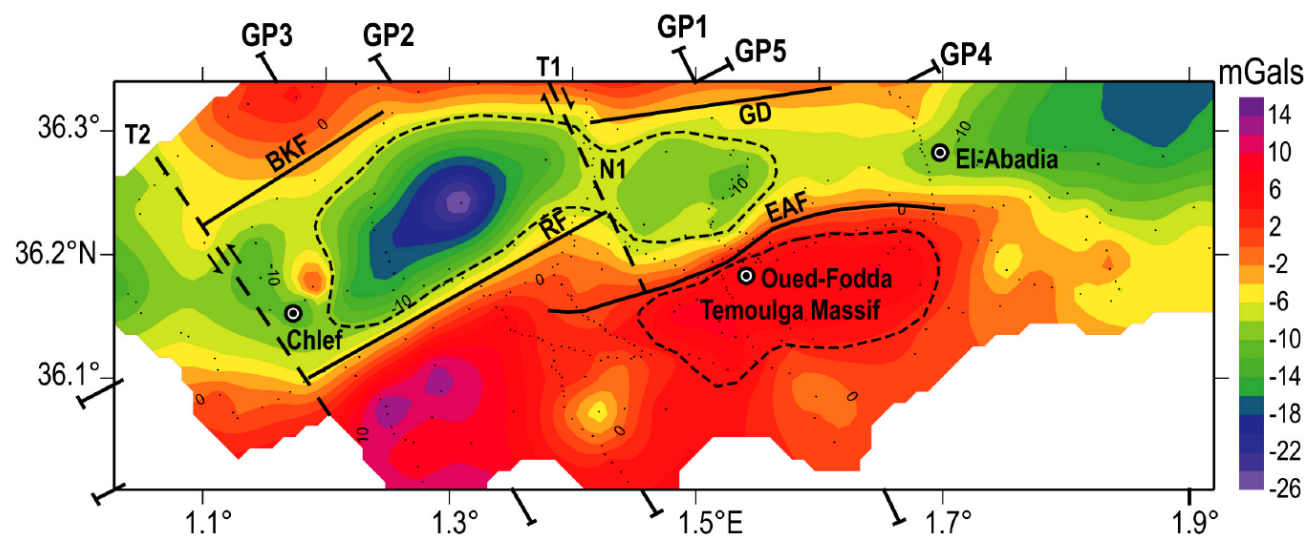

Fig. (2). Residual anomaly map of the Chélif Basin (units: mGals, isanomal equidistance: 2 mGals) and location of GP1 to GP5 sections. Small dots refer to gravity stations. T1 and T2 are interpreted as geological contacts. BKF: Boukadir fault, RF: Relizane fault, EAF: ElAsnam fault, GD: Gravimetric discontinuity. 


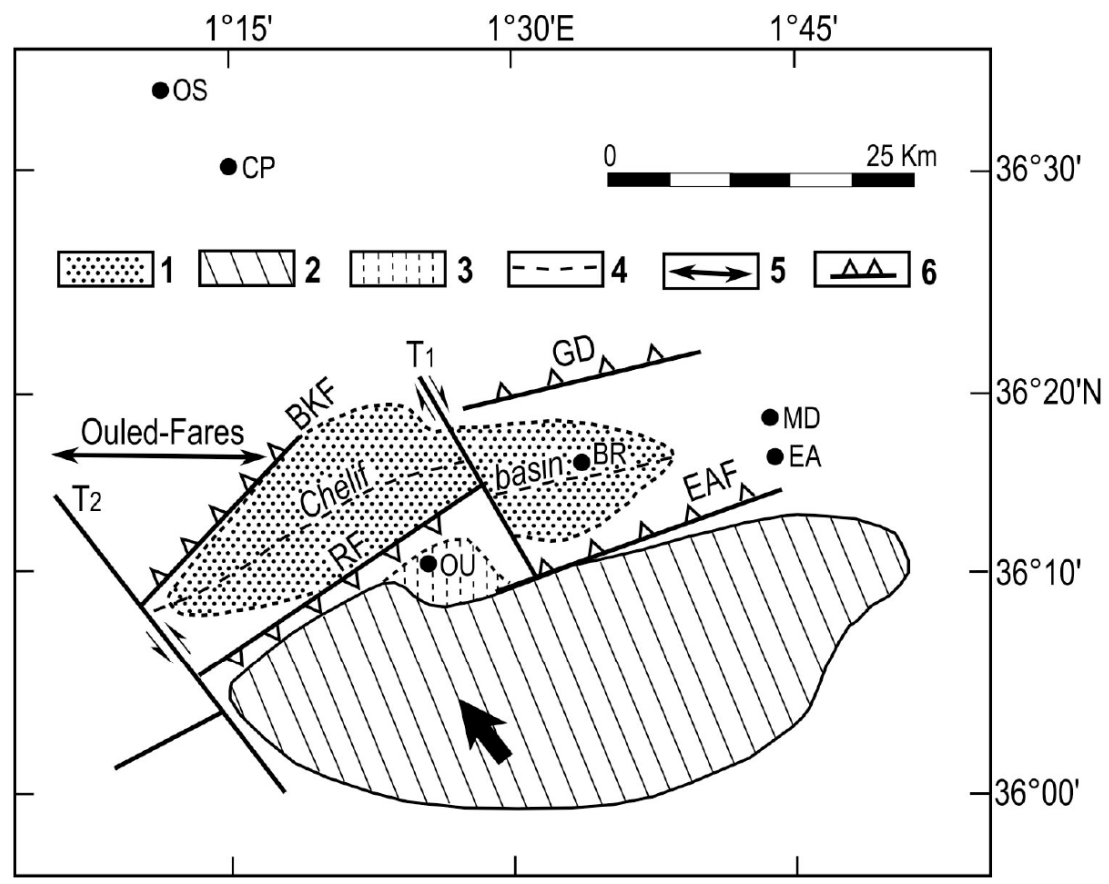

Fig. (3). Deep structural pattern of the study area and location of the AMS sites (black dots). OS: Ouled Sidi-Yahia, CP: Cinq palmiers, OU: Oum-Drou, BR: Béni-Rached, MD: Mdjaïa and EA: El-Abadia. 1: sedimentary basin, 2: shallow basement zone, 3: basement irregularity, 4: basin axis, 5: anticline, 6: thrusts. T1, T2: strike-slip faults. BKF: Boukadir fault, RF: Relizane fault, EAF: El-Asnam fault, GD: Gravimetric hidden fault. The black arrow indicates the direction of shortening.

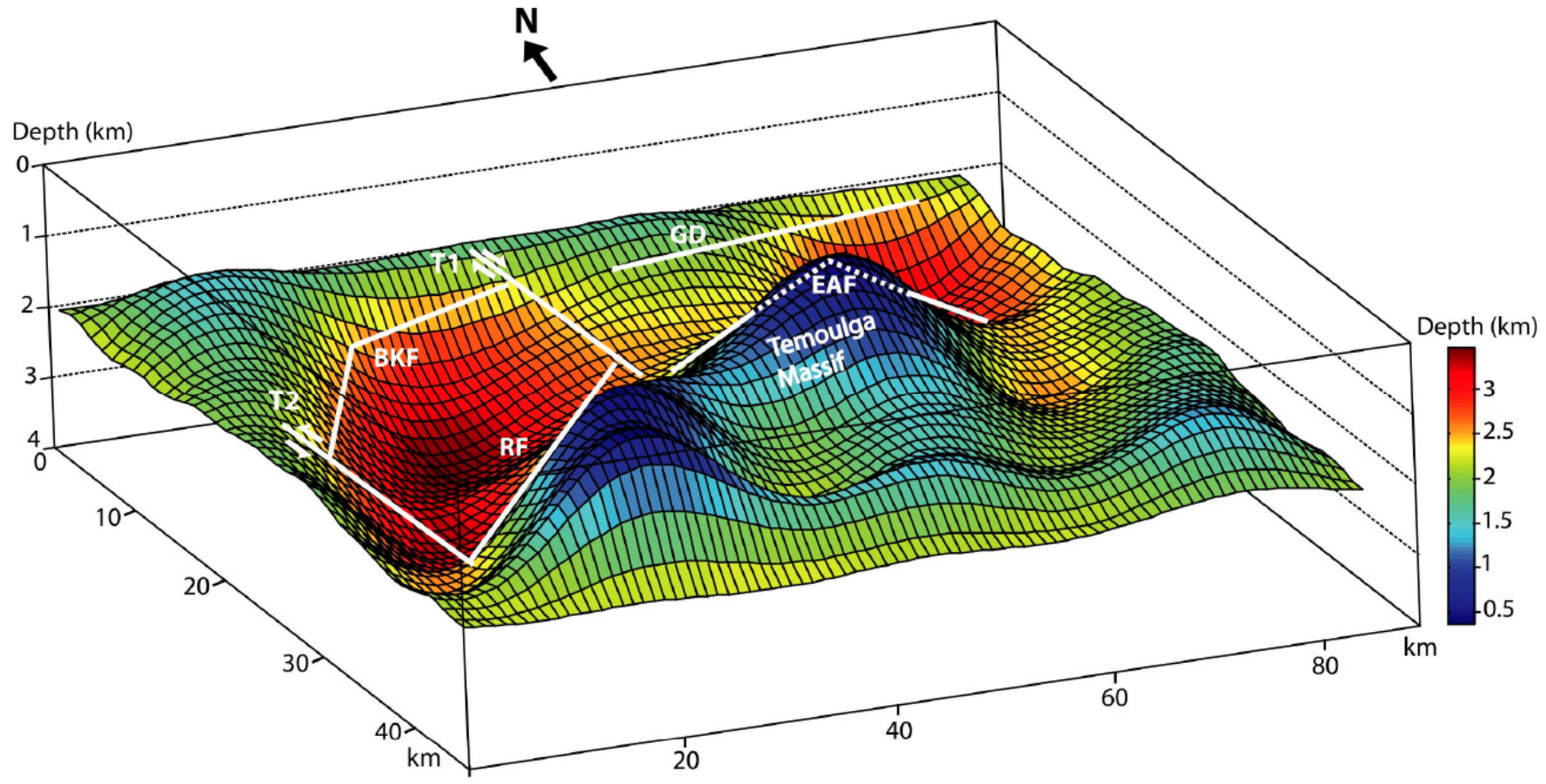

Fig. (4). 3D Gravity model, using the Parker-Oldenburg algorithm, computed with the residual anomaly data. T1, T2: strike-slip faults, BKF: Boukadir fault, RF: Relizane fault, EAF: El-Asnam fault, GD: gravimetric discontinuity related to a hidden fault.

cover by various terranes (Cretaceous, Jurassic, Messinian, etc.), we chose to carry out forward modeling according to five cross-sections (GP1 to GP5) (Fig. 5) by taking into account the density of each terrane. Cross-sections GP1 to GP3 are oriented SE-NW whereas cross-sections GP4 and GP5 are oriented SW-NE, which is perpendicular to discontinuities $\mathrm{T} 1$ and $\mathrm{T} 2$.
To confirm the offset of the basin and the basement uplift, at the indented area level, we performed forward modeling through three cross-sections (GP1 to GP3), chosen in the residual gravity map (Fig. 2). A 2.5D Model [19] was made using a base level definition representing the host rock anomaly mainly composed here of Cretaceous terranes. 

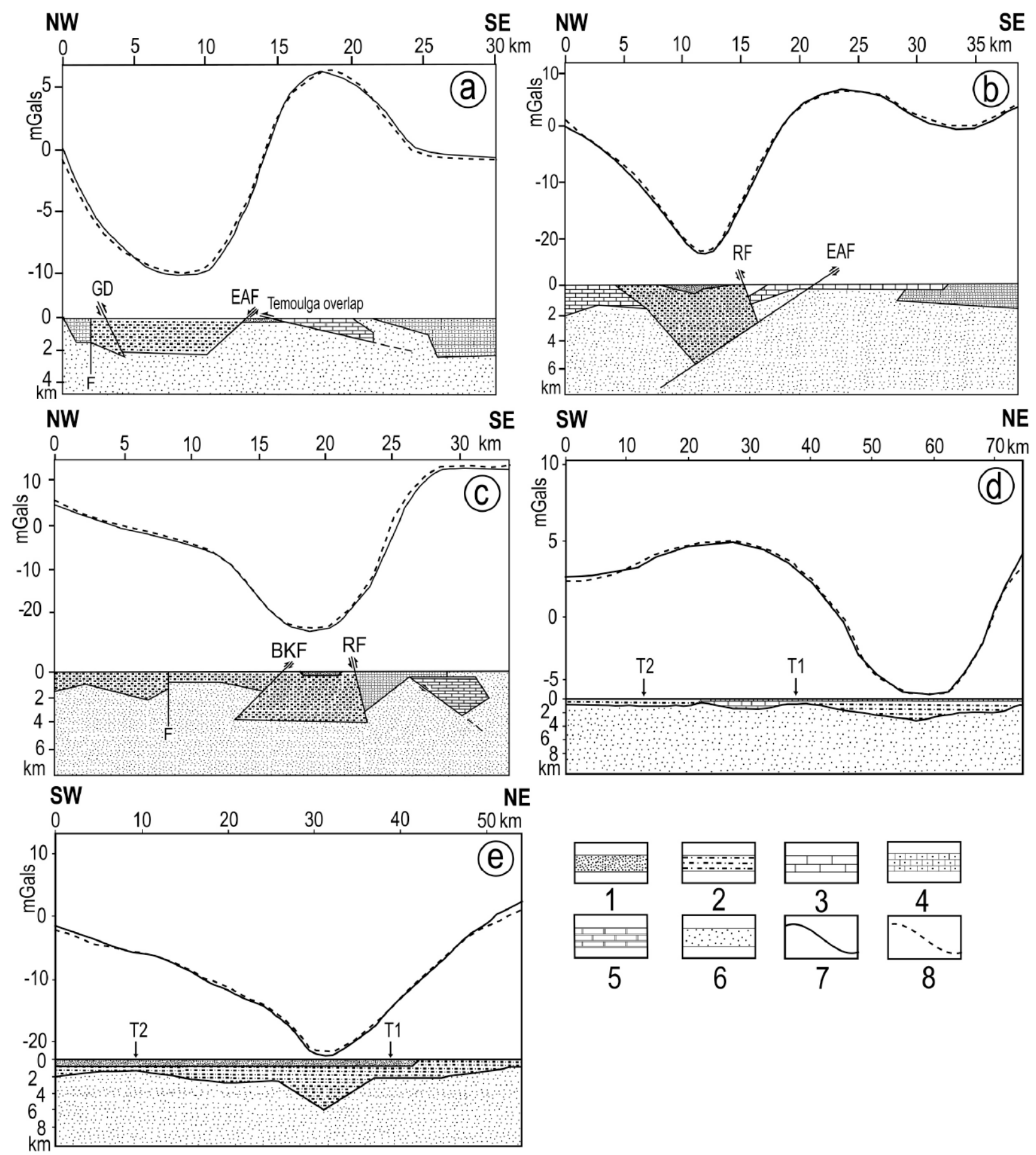

Fig. (5). Forward Gravity modeling and interpretation across sections GP1 to GP5 (a-e). 1- Quaternary, 2- Mio-Pliocene, 3- Messinian, 4Tortonian, 5-Cretaceous, 6- Jurassic, 7- Measured anomaly, 8-Computed Anomaly.

First, we need to appreciate the anomaly produced by the host rock (base level) before introducing the density contrast between the measured values of basin and host rock into the model. The residual anomalies (Fig. 2) show that they are of short wavelength and partly fit the contours of the outcrops. Several geologic sections $[4,11]$ helped to test different profiles to choose the base level [20]. For a base level higher than $14 \mathrm{mGals}$, the positive anomaly at the origin of the basement disappears, if it is lower than $8 \mathrm{mGals}$ the same anomaly shows higher values than those observed on the residual map. Comparison between two models with 10 and
12 mGals and with the geological map led to the best fit which corresponds to $12 \mathrm{mGals}$ base level value. This is consistent with the density values measured from specimens collected at different outcrops of the investigated area.

Density contrasts (in $\mathrm{g} / \mathrm{cm}^{3}$ ) [21] matching the observed anomaly are given as follows: Cretaceous (sandstones): 0.00 ; Tortonian (dark marls, succession of sandy limestones and marls): -0.12; Messinian (gypsum, marls, limestones and blue marls): -0.14; Mio-Pliocene (red sandy conglomerates, limestones and dune sands): -0.18; Quaternary (dark and grey mud, and conglomerates): -0.35 . 
The computed models do not correspond to unique solutions and the depths we deduced are considered as indicative values. Our models were constrained by densities measured on sampled rocks and by available geological data. since previous studies had assigned a $400 \mathrm{~m}$ thickness to the Quaternary sequence [2].

Profile GP1 (Fig. 5a) shows from NW towards SE a subvertical fault (observed on surface) separating Tortonian from Pliocene, then the gravimetric discontinuity GD, limiting the basin to the NW. With a dip of $\sim 60^{\circ}$ towards the SE, it overlaps Pliocene terranes. The EAF fault presents a dip of $\sim 40^{\circ}$ towards the NW. These two faults frame the central part of the Chélif Basin. The Temoulga Massif (Jurassic), overlapping Quaternary terranes, is limited by a probable fault which seems to reach the surface. It would thus be presented in the shape of a horst. The maximum depth of the basin is reached on profile GP2 (Fig. 5b).

Here, the EAF fault seems to be continued in-depth to limit the base of the basin as suggested by seismology [22]. On the GP3 profile (Fig. 5c), we can observe from NW towards SE a sub-vertical fault which controls the thickness variations of the Pliocene terranes, then the $\mathrm{BKF}$ and $\mathrm{RF}$ faults which limit the basin to this level. In the SE, the Jurassic terranes are uplifted but do not reach the surface and could be a westward continuation of the Temoulga Massif.

To confirm the shift of the Chélif Basin from west to east, we chose to make the GP4 and GP5 profiles pass through the central and western parts of the basin. The GP4 profile (Fig. 5d) crosses from SW towards NE the southern edge of the western part of the Chélif Basin and its central part which reaches a maximum depth of $\sim 3 \mathrm{~km}$. The GP5 profile (Fig. 5e) crosses from SW to NE the western part of the basin and the northern edge of its central part. The maximum depth reached on this level is $\sim 6 \mathrm{~km}$. We note that the difference between the depths observed on these models are appreciably different from those of the 3D model (Fig. 4). These differences can be explained by the use of average density values for the basement and the sedimentary cover.

Along the GP1 profile, the gravity map shows an anomaly exceeding $5 \mathrm{mGals}$, related to a Jurassic lens basement uplift through a thrust fault located at the SE of the EAF. This uplift probably brought to the surface the Cretaceous basement [21]. Because of the probable sphericity, the anomaly was modeled using a $2.5 \mathrm{D}$ technique [23]. This technique solves also a part of unknown densities and the complex nature of the host rocks, after removing a regional anomaly value of $12 \mathrm{mGals}$ corresponding to the Cretaceous basement anomaly [20].

The GP1 profile (Fig. 5a), which passes through the centre of the eastern part of the N1 anomaly and the zone where the basement uplifts, shows from SW to NE terranes of Mio-Pliocene age reaching a depth of $\sim 2 \mathrm{~km}$, shallower Tortonian terranes and a thin Messinian covering the uplifted Cretaceous basement. The deeper part of the basin, along this cross-section, is $\sim 2.8 \mathrm{~km}$. This model clearly shows an uplift of the basement, more contrasted in its irregularity near Oum Drou (OU, Fig. 3), which plays the role of indenter as observed in the structural pattern.

The GP2 Profile (Fig. 5b) is parallel to the GP1 and passes through the centre of the western part of N1 anomaly, where the maximum depth is $5.8 \mathrm{~km}$. From SW to NE, we may successively recognize Quaternary terranes reaching a maximum depth of $0.8 \mathrm{~km}$ at the SW and decreasing to the NE where we observe Mio-Pliocene terranes outcropping. The GP2 anomaly curve roughly fits the basement topography undulation. The maximum depth of the basin, according to this section, exceeds $5.5 \mathrm{~km}$ (western part of the $\mathrm{N} 1$ anomaly). The basin depth corresponding to the oriental part of the N1 anomaly reaches around $1.6 \mathrm{~km}$, a value lower than $1 \mathrm{~km}$ compared to that computed from GP1 profile. This difference can be explained by the fact that GP1 corresponds to the centre of the eastern part of the N1 anomaly while GP2 corresponds to its border. It confirms the offset of the basin and the dextral strike-slip of T1.

\section{PALAEOMAGNETISM}

After sampling in the field oriented cores $2.5 \mathrm{~cm}$ in diameter, using a portable gasoline-powered drilling machine, samples were cut, $2.2 \mathrm{~cm}$ in length. Magnetic susceptibilities were measured using a Bartington MS-2 susceptibility-meter. The values of the magnetic susceptibility are represented in a histogram in the 0.19$6.55 \times 10^{-4} \mathrm{SI}$ range with mean values for each site given in Table 1 and a distribution shown in Fig. (6a). The minimum and the maximum values belong to specimens from sites EA and OS respectively. Natural remanent magnetization (NRM) was measured using a LETI cryogenic magnetometer when the remanence is weak $\left(<10^{-3} \mathrm{~A} / \mathrm{m}\right)$ and a Spinner Schonstedt magnetometer when it is higher. Most of the $\mathrm{NRM}$ values are in the $10^{-4}-10^{-3} \mathrm{~A} / \mathrm{m}$ range (Fig. 6b). Thermal demagnetizations up to $680^{\circ} \mathrm{C}$ in some cases were performed using a Schonstedt TSD-1 furnace and gave results showing recent block rotations [3].

\section{4.a. Rock Magnetism}

A rock magnetic study was conducted to identify the magnetic minerals associated with the magnetic fabric. A series of isothermal remanent magnetization (IRM) to saturation (IRMs) curves was established on pilot samples for each site and some IRMs were thermally demagnetized (Fig. 7).

Specimens from site EA (Fig. 7a, b), even if they show the presence of a weak coercivity mineral, probably magnetite, did not saturate at $1.2 \mathrm{~T}$ owing to the presence of a high coercivity mineral. They were subjected to successive demagnetizations with a progressive step of $50^{\circ} \mathrm{C}$ in the $100^{\circ} \mathrm{C}-600^{\circ} \mathrm{C}$ range, then in ambiant IRMs corresponding to $470^{\circ} \mathrm{C}$ (specimen EAO3A), $550^{\circ} \mathrm{C}$ and $600^{\circ} \mathrm{C}$ heating steps. A loss of intensity, due to the presence of goethite, is produced between room temperature and $85^{\circ} \mathrm{C}$ (Fig. 7a, b). We noticed that no relative saturation is produced at $600^{\circ} \mathrm{C}$ : minerals responsible for this high coercivity could be a type of sulphide which may have been transformed below this temperature into magnetite.

Specimens from sites OD, OS, CP, MD and OU show the presence of two magnetic minerals, one of weak coercivity, probably of magnetite type, the second of higher coercivity, possibly goethite or sulphides. As an example, specimen OD12A (Fig. 7c) shows a weak coercivity mineral, probably magnetite or Ti-magnetite, whereas specimen OD13A 
Table 1. AMS and Associated Parameters

\begin{tabular}{|c|c|c|c|c|c|c|c|c|c|c|c|c|c|c|}
\hline Site & $\mathbf{n}$ & $\mathbf{D}_{\mathbf{b}}$ & $\mathbf{I}_{\mathbf{b}}$ & $\mathbf{E}_{\mathbf{v}}$ & $\sigma$ & $\mathbf{D}_{\mathbf{a}}$ & $\mathbf{I}_{\mathbf{a}}$ & $\mathbf{E}_{\mathbf{v}}$ & $\sigma$ & Bulk $\left(10^{-4} \mathrm{SI}\right)$ & AMS Tensors & Rotation & Strike/Dip & Age \\
\hline \multirow{3}{*}{$\mathrm{CP}$} & \multirow{3}{*}{7} & 56.0 & 16.7 & 5.71 & 0.18 & 80.2 & 18.5 & 5.71 & 0.24 & \multirow{3}{*}{0.4878} & $\mathrm{~K}_{1}$ & & \multirow{3}{*}{$46 / 54$} & \multirow{3}{*}{$\begin{array}{l}\text { M-U Pliocene } \\
\text { (E-W folds) }\end{array}$} \\
\hline & & 323.2 & 2.8 & 5.12 & 0.20 & 340.7 & 26.5 & 5.76 & 0.22 & & $\mathrm{~K}_{2}$ & & & \\
\hline & & 216.5 & 78.2 & 6.13 & 0.09 & 196.8 & 57.2 & 6.77 & 0.03 & & $\mathrm{~K}_{3}$ & $35.8^{\circ}$ & & \\
\hline \multirow{3}{*}{ OS } & \multirow{3}{*}{16} & 119.9 & 14.5 & 10.96 & 0.32 & 301.6 & 11.3 & 11.56 & 0.31 & \multirow{3}{*}{2.9097} & $\mathrm{~K}_{1}$ & & \multirow{3}{*}{$110 / 35$} & \multirow{3}{*}{$\begin{array}{l}\text { M-U Pliocene } \\
\text { (E-W folds) }\end{array}$} \\
\hline & & 220.1 & 26.4 & 10.77 & 0.27 & 36.2 & 11.8 & 11.79 & 0.25 & & $\mathrm{~K}_{2}$ & & & \\
\hline & & 6.3 & 61.9 & 13.76 & 0.19 & 169.4 & 72.3 & 13.96 & 0.20 & & $\mathrm{~K}_{3}$ & $8.4^{\circ}$ & & \\
\hline \multirow{3}{*}{$\mathrm{OU}$} & \multirow{3}{*}{10} & 80.6 & 14.5 & 7.95 & 0.16 & 119.1 & 3.1 & 7.39 & 0.27 & \multirow{3}{*}{0.1834} & $\mathrm{~K}_{1}$ & & \multirow{3}{*}{$267 / 16$} & \multirow{3}{*}{$\begin{array}{c}\text { M-U Pliocene } \\
\text { (E-W folds) }\end{array}$} \\
\hline & & 181.2 & 55.5 & 5.99 & 0.29 & 23.7 & 7.2 & 6.64 & 0.32 & & $\mathrm{~K}_{2}$ & & & \\
\hline & & 347.8 & 30.8 & 6.44 & 0.27 & 162.9 & 84.9 & 8.34 & 0.30 & & $\mathrm{~K}_{3}$ & $1.9^{\circ}$ & & \\
\hline \multirow{3}{*}{ EA } & \multirow{3}{*}{6} & 267.9 & 5.4 & 4.86 & 0.21 & 66.6 & 21.1 & 5.82 & 0.04 & \multirow{3}{*}{0.2732} & $\mathrm{~K}_{1}$ & & \multirow{3}{*}{$80 / 45$} & \multirow{3}{*}{$\begin{array}{l}\text { L-M Pliocene } \\
\text { (N110 folds) }\end{array}$} \\
\hline & & 0.5 & 14.9 & 4.72 & 0.11 & 330.6 & 16.8 & 5.44 & 0.04 & & $\mathrm{~K}_{2}$ & & & \\
\hline & & 142.5 & 78.8 & 5.15 & 0.11 & 203.2 & 63.2 & 5.52 & 0.05 & & $\mathrm{~K}_{3}$ & $42.2^{\circ}$ & & \\
\hline \multirow{3}{*}{ MD } & \multirow{3}{*}{18} & 128.4 & 0.6 & 10.97 & 0.34 & 71.4 & 15.1 & 15.88 & 0.26 & \multirow{3}{*}{1.0858} & $\mathrm{~K}_{1}$ & & $35 / 16$ & \multirow{3}{*}{$\begin{array}{c}\text { U Tortonian } \\
\text { (NW-SE folds) }\end{array}$} \\
\hline & & 216.7 & 25.9 & 10.39 & 0.32 & 338.8 & 23.1 & 15.68 & 0.22 & & $\mathrm{~K}_{2}$ & & $270 / 44$ & \\
\hline & & 45.2 & 74.6 & 15.33 & 0.16 & 195.6 & 62.9 & 16.74 & 0.09 & & $\mathrm{~K}_{3}$ & $34.6^{\circ}$ & $48 / 33$ & \\
\hline
\end{tabular}

Bulk magnetic susceptibility $\left(\right.$ Bulk $=\left(\mathrm{K}_{1}+\mathrm{K}_{2}+\mathrm{K}_{3}\right) / 3$ ) of the mean tensor at each site. $\mathrm{K}_{1}, \mathrm{~K}_{2}, \mathrm{~K}_{3}$ are the maximum, intermediate and minimum axes of the AMS tensor. $\mathrm{n}=$ number of specimens, $\left(\mathrm{D}_{\mathrm{b}} / \mathrm{I}_{\mathrm{b}}\left(\mathrm{D}_{\mathrm{a}} / \mathrm{I}_{\mathrm{a}}\right)\right.$ : Declination $\left(^{\circ}\right) /$ Inclination $\left(^{\circ}\right)$ before (after) unfolding. Ev, $\sigma$ : eigenvector and standard deviation respectively [25]. For MD synclinal, strikes/dips of layer are from opposite flanks. Ages and stress directions (Fig. 9, Table 1) are from Meghraoui [4].
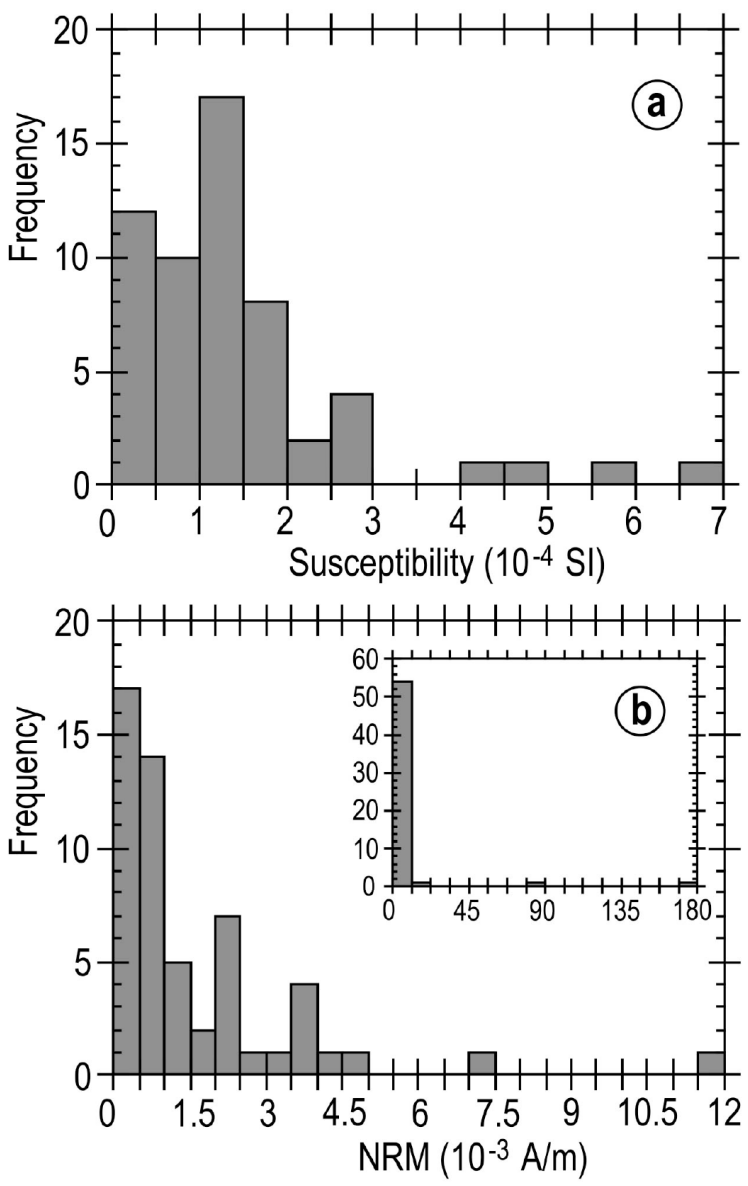

Fig. (6). Intensity histogram of the magnetic susceptibility (a) and of the remanent magnetization (b) measured on the sampled specimens.

(Fig. 7d) from the same site, exhibits a higher coercivity and saturation is not reached before $1.2 \mathrm{~T}$. Its thermal demagnetization is in agreement with two possible minerals, one showing a drop of magnetization value before $100^{\circ} \mathrm{C}$, related to goethite and the other characteristic of hematite since blocking temperature of about $680^{\circ} \mathrm{C}$ is reached. Specimen OS04A (Fig. 7e) displays the same behaviour as specimen OD13A but with a small amount of a third mineral at around $580^{\circ} \mathrm{C}$, probably related to the presence of magnetite. While for specimens CP35B and OU17A (Fig. 7f, h), saturation is not reached before 1.2 T, specimen MD03B (Fig. 7g) saturates more easily which agrees with the presence of a small amount of this mineral.

\section{4.b. Anisotropy of Magnetic Susceptibility}

AMS measurements were carried out on 57 specimens with a minimum of 6 specimens per site using a DSML-1 Schonstedt spinner magnetometer. A normalized susceptibility tensor was calculated for each specimen using the statistical tensor of Jelinek [24]. For each site, data were subjected to eigenvector analysis using the Spheristat program [25]. The corrected anisotropy degree P' [26] generally varies between 1.03 and 1.38 (Fig. 8). Sandstone specimens from El-Abadia (site EA) can reach 1.82. AMS is controlled mainly by the mean preferred orientation of the paramagnetic and/or diamagnetic matrix, with a ferromagnetic contribution when the mean bulk magnetic susceptibility is $\mathrm{K}_{\mathrm{m}} \leq 3-5 \times 10^{-4} \mathrm{SI}$ and the corrected anisotropy degree is $\mathrm{P}^{\prime}<1.35$ (in our case: $\mathrm{K}_{\mathrm{m}}=0.19-6.55 \times 10^{-4} \mathrm{SI}$ and $\mathrm{P}$ ' 1.82). However it reflects the mean preferential orientation of the ferromagnetic fraction when $\mathrm{K}_{\mathrm{m}} \geq 10^{-3} \mathrm{SI}$ and $\mathrm{P}^{\prime}>>1.35$ [27,28]. Except for site EA, most of our specimens show that the magnetic fabric is probably influenced by a paramagnetic and/or a diamagnetic matrix. 

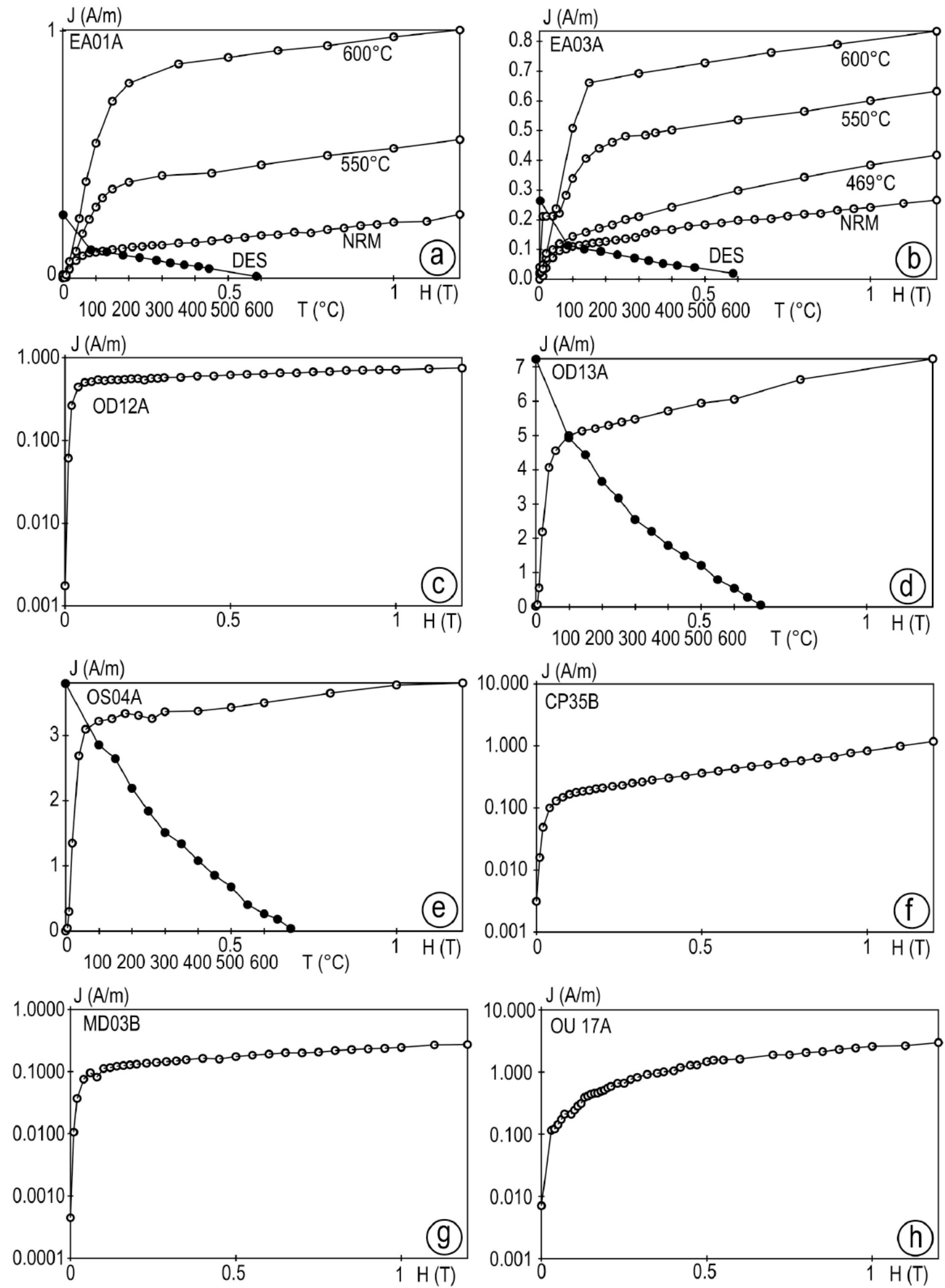

Fig. (7). Isothermal remanent magnetization (IRM) to saturation (IRMs) diagrams (open dots) for specimens from sites EA (a, b), OD (c, d), $\mathrm{OS}(\mathbf{e}), \mathrm{CP}(\mathbf{f}), \mathrm{MD}(\mathbf{g})$ and $\mathrm{OU}(\mathbf{h})$ and some of their respective thermal demagnetization curves (black dots) after $600^{\circ} \mathrm{C}(\mathbf{a}, \mathbf{b})$ or at room temperature (d, e). NRM: natural remanent magnetization, $550^{\circ} \mathrm{C}$ : IRM after heating at $550^{\circ} \mathrm{C}$.

The shape parameter T (Fig. 8) indicates a mixed magnetic fabric (foliation and lineation) for all sites, except for site OS where the foliation prevails [29].
Equal area projections show a cluster of the AMS directions after bedding corrections (Fig. 9, Table 1). The mean $\mathrm{K}_{1}$ direction for sites $\mathrm{CP}$, EA and MD shows shallow 
inclinations (sub-horizontal) (Fig. 9, Table 1) with a mean direction of: $\mathrm{D}=72.8^{\circ}, \mathrm{I}=18.3^{\circ}, \alpha_{95}=10.9^{\circ}$. The direction of the $\mathrm{K}_{3}$ shows steep well-grouped inclinations (Fig. 9) $\mathrm{D}=2.7^{\circ}\left(192.1^{\circ}\right), \quad \mathrm{I}=74.7^{\circ}\left(68.6^{\circ}\right), \quad \alpha_{95}=29.6^{\circ}\left(11.5^{\circ}\right)$ for $\mathrm{n}=5$ before (after) bedding corrections, which suggests that the primary direction of the sedimentary magnetic fabric is preserved since the fold test is positive. If we take into account the 3 sites $\mathrm{CP}$, EA and $\mathrm{MD}$, we obtain: $\mathrm{D}=125.1^{\circ}\left(198.4^{\circ}\right), \mathrm{I}=85.6^{\circ}\left(61.1^{\circ}\right), \alpha_{95}=23.0^{\circ}\left(5.9^{\circ}\right)$ and the fold test remains positive.

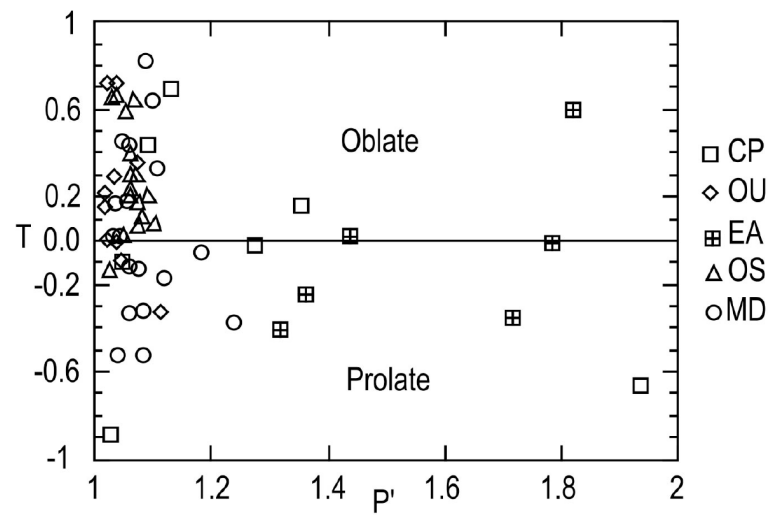

Fig. (8). Shape parameter (T) vs corrected anisotropy degree (P') for all the specimens; symbols denote the specific sites.

\section{DISCUSSION AND CONCLUDING REMARKS}

The $\mathrm{N} 160^{\circ}$ compressional direction deduced from neotectonics [4], in agreement with the focal mechanisms of the last seismic events in the El-Asnam area $(1954,1980)$, did not vary significantly during the Pliocene-Pleistocene period. The $\mathrm{K}_{3}$ and $\mathrm{K}_{1}$, minimum and maximum axis of the AMS tensor respectively, which represents here the compressional and extensional direction allowed us to compute the rotation values (Table 1). The rotation angle recorded is measured between the $\mathrm{K}_{3}$ axis and the present day magnetic field direction. We studied sandstones dating from the Tortonian (MD), lower-middle Pliocene (EA) and middle-upper Pliocene (CP, OS, OU), we may interpret this compressional direction as a shortening direction of nappes induced by a rigid Cretaceous block indenter. The rotations of blocks or nappes deduced from AMS measurements represent rotations of the magnetic lineation or foliation direction [30-32]. Except for site OU where no significant rotation was detected $\left(\sim 2^{\circ}\right)$, rotations obtained using AMS were clockwise (Table 1) even if remagnetizations occurred [3].

The large rotations found using AMS indicate that remagnetization values in each site were acquired during folding (Mdjaïa syncline (MD), Béni-Rached anticline, near El-Abadia) or after folding giving a mean rotation value of $\sim 3.5^{\circ}$ Ma since the Tortonian period.

During the upper Tortonian/Messinian period, NE-SW compressive movements caused E-W to WNW-ESE trending folds (surface traces are also observed as far as the Oran area $[33,34])$. During the lower Pliocene, an extensive episode led to syn-sedimentary normal faults with a $\mathrm{N} 130^{\circ}$ main trend, compatible with the extensional direction recorded by $\mathrm{K}_{1}$ at sites OS and OU. A major unconformity developed in the
Chélif Basin [35] as a result of an upper Pliocene compressive phase striking $\mathrm{N} 022^{\circ}$, leading to $\mathrm{N} 110^{\circ}$ folds. This trend corresponds to the sedimentary transport direction which is the extensional direction carried by $\mathrm{K}_{1}$ [29] (Fig. 9). It varies from NNE-SSW during Tortonian, $\mathrm{N} 112^{\circ}$ to $\mathrm{N} 70^{\circ}$ during lower-upper Pliocene [4], compatible with the results obtained here. Moreover clay minerals were transported from the uphill slopes far to the NE and deposited in the Chélif Basin along a NE-SW trench during its structural evolution [36]. The transport direction is shown by the AMS $\mathrm{K}_{1}$ direction (Fig. 9). The rapid deposition of clastic material grains in flood plains occurs through tectonic activity as shown in the last seismic event in El-Asnam [37]. It might be related to the pattern change of features in the orientation of the sedimentary horizontal transport direction (Fig. 8, sites $\mathrm{OS}, \mathrm{OU})$. It is also obvious that some local transport directions trending northwestwards could be related to the uplift of the basement in relationship with the NW-SE transpressional regime in the Tortonian.

According to palaeomagnetic results, the Oum Drou site either was not subjected to any significant rotation or was affected by a Quaternary remagnetization [3]. The proposed structural model deduced from gravity data is supported by the first assumption and also by the AMS results in this site where no significant rotation was recorded $\left(\sim 2^{\circ}\right)$ because in front of the indenter we do not expect any rotation [7]. In fact, analogous models in a transpressional regime show that the values of rotations decrease away from the indenter zone [7], in agreement with the results obtained at the western side of T1 fault. As an example, Béni-Rached recorded a rotation of $\sim 25^{\circ}$ and far to the east, Mdjaiia recorded a rotation of only $\sim 10^{\circ}$ deduced from components of remanent magnetizations (CRM) [3]. We expect a large rotation degree at the BR site on the basis of the AMS data. In the Oum Drou zone (site OU), either no significant palaeomagnetic rotation was recorded or a secondary magnetic fabric, completely overprinted (superimposed on) the primary fabric (mostly secondary minerals), may explain that remagnetizations could have been recorded later during the Quaternary era.

The rotations recorded by CRM were partially subjected to successive subsequent remagnetizations. They may record full or partial rotation values. As an example, both AMS and CRM recorded a $\sim 2^{\circ}$ clockwise rotation at site OU, while they recorded $\sim 35^{\circ}$ and $\sim 10^{\circ}$ clockwise rotations at site MD, respectively. Thus, according to AMS and the $\mathrm{K}_{1}, \mathrm{~K}_{3}$ plane we may be able to restore the total amount of rotation in the sites we studied (Table 1).

No vertical offset of $\mathrm{T} 1$ and $\mathrm{T} 2$ faults was detected by the gravity model, but the dextral shearing of $\mathrm{T} 1$ fault was confirmed. We think that T2 is a sinistral shearing. The T2 fault cross-cuts both the BKF and RF faults (Fig. 2) and is probably contemporaneous with the $\mathrm{T} 1$ fault. The shape of the indenter represented by shallow Cretaceous hard rocks was probably induced by a $\mathrm{N}-\mathrm{S} \pm 20^{\circ}$ compressional direction. This deformation is compatible with almost all of the oriented E-W folds (Table 1). The NW-SE and the NESW folds are accommodated by $\mathrm{N} 20^{\circ}$ and $\mathrm{N} 160^{\circ}$ oriented compressional phases, respectively, lower to upper Pliocene and Quaternary in age [4]. 


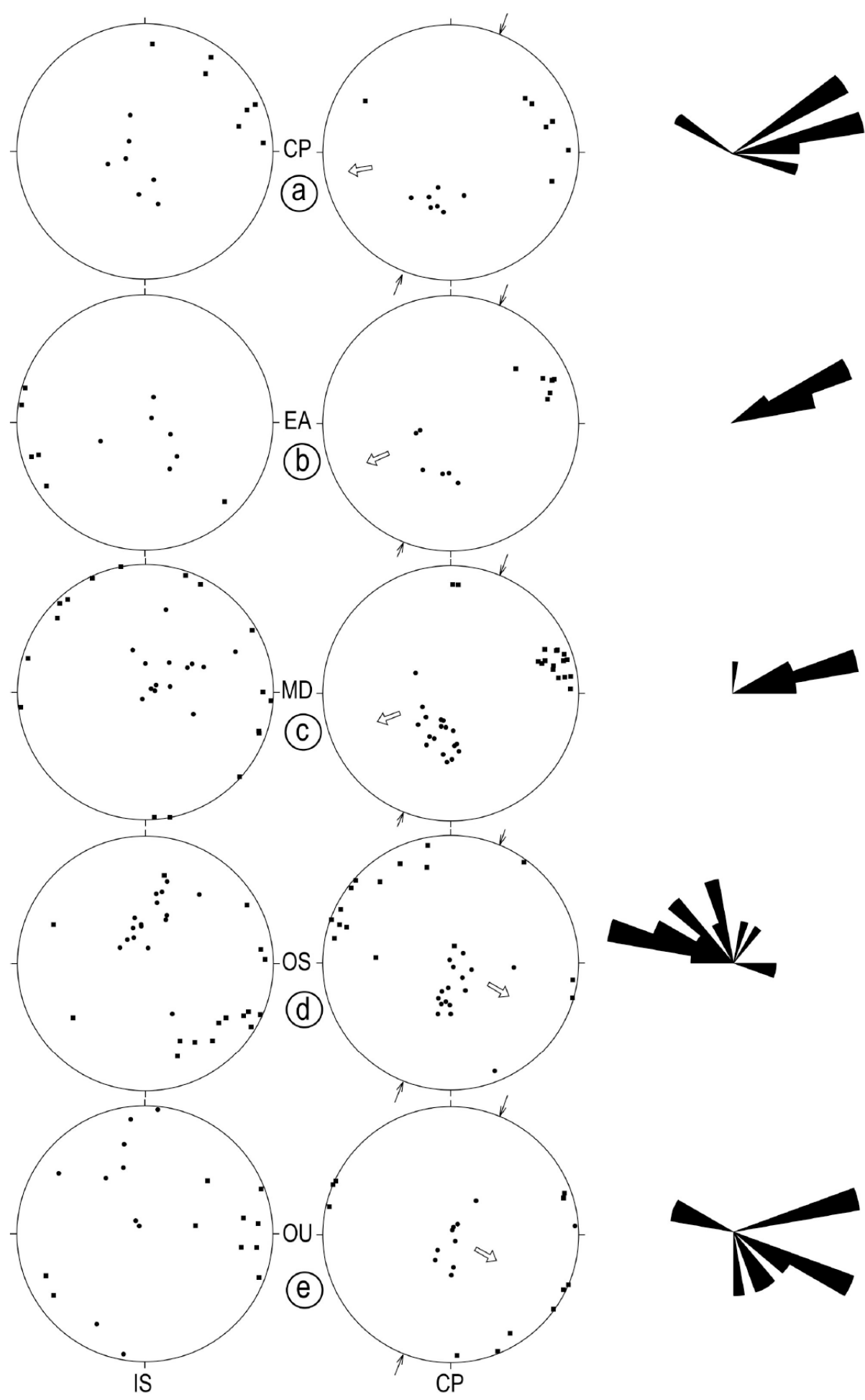

Fig. (9). Possible palaeocurrent directions from the AMS data of the studied sedimentary sites before (left) and after (centre) bedding corrections. Lower hemisphere equal area projections of $\mathrm{K}_{1}$ (solid square) and $\mathrm{K}_{3}$ (solid circle), showing compressional direction (solid opposite arrows) and absolute palaeocurrent directions (open arrows). Rose diagrams (right) showing the azimuthal distribution of $\mathrm{K}_{1}$ axes.

The Chélif Basin was elongated ENE-WSW during the lower Pliocene, its northern part is subjected to a clockwise rotation related to the shortening direction which changed (NNW-SSE) creating a subdivision and an extrusion to the east. The seismotectonic data of Meghraoui et al. [2] are in agreement with our gravity data (Fig. 2), which support such a subdivision and lateral extrusion. The AMS and palaeomagnetic data [3] confirm such a clockwise rotation induced by shortening. Tapponnier et al. [9] and Piqué et al. [38] proposed an indentation model on a large scale, where lateral escape occurred during indentation through a stress field dominated by $\sigma_{1}$ oriented roughly north-south. We think that the shortening in the Chélif Basin is associated at a small (regional) scale with an indenter composed of hard 
rocks (outcropping in some areas as for the Temoulga Massif). Between the RF and EAF faults, the indenter followed the geometry of the faults and induced, by squeezing, the subdivision of the basin (Figs. 2, 4). In Fig. (4), it can be seen that the topography of the basement is in agreement with the proposed indentation. The deepening of the Chélif compressional basin [7,39] is related to the shortening determined using the different methods (Neotectonics, Gravity, Palaeomagnetism).

\section{ACKNOWLEDGEMENTS}

This work benefited from the financial support of the French-Algerian scientific programme $n^{\circ} 93 \mathrm{MEN} 247$ and from the University of Algiers (USTHB) for the field support. We are indebted to J.B. Edel for his constructive remarks on the early draft version. We also gratefully acknowledge L. Fleurian's help in improving and polishing the English. Our special thanks to the three anonymous reviewers for helpful reviews of the final version of the manuscript.

\section{REFERENCES}

[1] Groupe de Recherche Néotectonique de l'Arc de Gibraltar,'L'histoire tectonique récente (Tortonien à Quaternaire) de l'arc de Gibraltar et des bordures de la mer d'Alboran", Bull. Soc. Géol. France, (7), vol. XIX, no. 3, pp. 575-614, 1977.

[2] M. Meghraoui, A. Cisternas, and H. Philip,"Seismotectonics of the lower Chélif basin: structural background of the E1-Asnam (Algeria) earthquake", Tectonics, vol. 5, no.6, pp. 809-836, 1986.

[3] T. Aïfa, Feinberg, H., Derder, M., and N. Merabet,"Rotations paléomagnétiques récentes du bassin du Chéliff (Algérie)", C. R. Acad. Sci. Paris, II, vol. 314, pp. 915-922, 1992.

[4] M. Meghraoui, Etude néotectonique de la région nord-ouest d'ElAsnam: Relation avec le séisme du 10 octobre 1980, Thesis, University of Paris, France, 1982, p. 210.

[5] M. Meghraoui, J.L. Morel, J. Andrieux, and M. Dahmani,"Tectonique plio-quaternaire de la chaîne tello-rifaine et de la mer d'Alboran; une zone complexe de convergence continentcontinent", Bull. Soc. Géol. France, vol. 167, no. 1, pp. 141-157, 1996.

[6] J.L. Morel, and M. Meghraoui,"Goringe-Alboran-Tell tectonic zone: A transpression system along the Africa-Eurasia plate boundary", Geology, vol. 24, pp. 755-758, 1996.

[7] Ph. Davy, and P.R. Cobbold,"Indentation tectonics in nature and experiment. 1- Experiments scaled for gravity", Bull. Geol. Inst. Uppsala, New Series, vol. 14, pp. 129-141, 1988.

[8] V. Jelinek,"Characterization of magnetic fabric of a rock", Tectonophysics, vol. 79, pp. 563-567, 1981.

[9] P. Tapponnier,"Evolution tectonique du système alpin en Méditerranée: poinçonnement et écrasement rigide-plastique", Bull. Soc. Géol. France, 7, vol. XIX, no. 3, pp. 437-460, 1977.

[10] T. Aifa, H. Feinberg, M.E.M. Derder, and M. Merabet,"'Contraintes magnéto-stratigraphiques sur la durée de l'interruption des communications marines en Méditerrannée occidentale pendant le Messinien", Geodiversitas, vol. 25, no. 4, pp. 617-631, 2003.

[11] M. Meghraoui,"Géologie des zones sismiques du Nord de l'Algérie (paléosismicité, tectonique active et synthèse sismotectonique)", Ph.D. Thesis, University of Paris sud, France, p. 356, 1988.

[12] O. Kirèche, Etude géologique structurale des massifs de la plaine du Chéliff (Doui, Rouina, Témoulga), Thesis, USTHB, Algiers, Algeria, 1977, p. 147.

[13] M. Bezzeghoud, D. Dimitrov, J.C. Rueg, and K. Lammali,"Faulting mechanism of the El Asnam (Algeria) 19541980 earthquakes from modeling of vertical movements", Tectonophysics, vol. 249, pp. 249-266, 1995.

[14] T. Aïfa, D. Belhaï, and O. Merle,"Neogene palaeomagnetic rotations of the Chenoua Massif (Northern Algeria)", Geol. Carpathica, vol. 49, no. 3, pp. 195-196, 1998

[15] N. Ousmer, M. Amokrane, F. Bedouhene, F. Benzerga, M. Briedj, M. Djender, B. Becis, M. Berabah, and I. Chempelev,"Le séisme de Chlef (ex El-Asnam) du 10.10.1980. Répartition de l'énergie sismique et sa relation avec la tectonique", Bull. Serv. Géol. Algérie, vol. 50, pp. 27-44, 1984.

[16] D. El-Foul,'Investigations of earthquake hazards in the Ouled Farès area", Eight World Conference on Earthquake Engineering, San Francisco, California, Proc., 1984, vol. 1, pp. 61-68.

[17] J. Motyka, and S. Witczak,"Groundwater chemistry in the vicinity of the Ouled Farès area, Northern margin of the Chéliff Valley $(\mathrm{N}$ Algeria)", Ann. Soc. Geologorum. Poloniae, vol. 62, pp. 317-335, 1992.

[18] D. Gomez-Ortiz, and B.N.P. Agarwal,"3DINVER.M: a MATLAB program to invert the gravity anomaly over a 3D horizontal density interface by Parker-Oldenburg's algorithm", Comput. Geosci., vol. 31, pp. 513-520, 2005.

[19] R.H. Godson,"Gravpoly, A Modification of A Three-Dimensional Gravity Modelling Program", Open File Report, US, Geological Survey, 83-346, pp. 1-53, 1983.

[20] S.D. Dods, D.J. Teskey, and P.J. Hood,'The new series of $1: 1,000.000$-scale magnetic anomaly maps of the Geological Survey of Canada; compilation techniques and interpretation", In: The Utility of Regional Gravity and Magnetic Anomaly Maps, W.J. Hinze, Ed., Soc. Explor.Geophys. Tulsa, Ok., USA, 1985, pp. 6987.

[21] A. Ydri, Etude gravimétrique de la région d'Ech-Chlef, Thesis, USTHB, Algiers, Algeria, 1988, p. 89.

[22] M. Ouyed, M. Meghraoui, A. Cisternas, A. Deschamps, J. Dorel, J. Fréchet, R. Gaulon, D. Hatzfeld, and H. Philip,"Seismotectonics of the El-Asnam earthquake", Nature., vol. 292, pp. 26-31, 1981.

[23] D. Plouff,"Derivation of formulas and Fortran programs to compute gravity anomalies of prisms", Open File Report, US, Geological Survey, p. 83, 1975.

[24] V. Jelinek,"Statistical processing of anisotropy of magnetic susceptibility measured on groups of specimens", Studia. Geophysica. Geodaetica, vol. 22, pp. 50-62, 1978

[25] R.M. Stesky, and G.W. Pearce, Spheristat 2.2 for Windows, Pangaea Scientific, Brockville, Ontario, Canada, 1995, p. 199.

[26] V. Jelinek,"Characterization of magnetic fabric of a rock", Tectonophysics, vol. 79, pp. 563-567, 1981.

[27] P. Rochette,"Magnetic susceptibility of the rock matrix related to magnetic fabric studies", J. Struct. Geol., vol. 9, pp. 1015-1020, 1987.

[28] D.H. Tarling, and F. Hrouda, The Magnetic Anisotropy of Rocks, Chapman and Hall, London, 1993, p. 217.

[29] B. Liu, Y. Saito, T. Yamazaki, A. Abdeldayem, H. Oda, K. Hori, and Q. Zhao,"Paleocurrent analysis for the Late PleistoceneHolocene incised-valley fill of Yantze delta, China by using anisotropy of magnetic susceptibility data", Marine Geol., vol. 176, pp. 175-189, 2001.

[30] G.J. Borradaile, and B. Henry,"Tectonic applications of magnetic susceptibility and its anisotropy", Earth Sci. Rev., vol. 42, pp. 4-93, 1997.

[31] A. Winkler, L. Alfonsi, F. Florindo, L. Sagnotti, and F. Peranza,"The magnetic anisotropy of rocks: principles, techniques and geodynamic applications in the Italian peninsula", Ann. Geofisica, vol. XL, 3, pp. 729-740, 1997.

[32] A. Winkler, and L. Sagnotti,"Anisotropies of the anhysteretic remanence and magnetic susceptibility of marly clays from central Italy", Ann. Geofisica, vol. 37, pp. 1027-1035, 1994.

[33] G. Thomas,"Mise en évidence de décrochements dextres Est-Ouest d'âge quaternaire en Algérie nord-occidentale", C.R. Acad. Sci., vol. 283, pp. 893-896, 1979.

[34] G. Thomas,"Géodynamique d'un bassin intramontagneux, le bassin du bas Chélif occidental (Algérie) durant le mio-plioquaternaire", Ph.D. Thesis, University of Pau, France, 1985, p. 594.

[35] A. Perrodon,"Etude géologique des bassins néogènes sub-littoraux de l'Algérie nord occidentale", Publ. Serv. Carte Géol. Algérie, vol. 12, p. 343, 1957.

[36] R. Sabrier, and J. Neurdin-Trescartes,"Le remplissage du bassin intramontagneux néogène du Chélif (Algérie): interprétation géodynamique par les minéraux argileux", C.R. Acad. Sci., vol. 313, pp. 923-928, 1991.

[37] M. Meyer, M. Meghraoui, P. Tapponnier, G. Shunmin, X. Hongfa, C. Zhita, and C. Shuahua,"Comparaison morphologique des escarpements de failles normales et inverses synchrones du tremblement de terre d'El Asnam, Algérie (10 octobre, 1980)", C.R. Acad. Sci., vol. 310, pp. 139-146, 1990. 
[38] A. Piqué, L. Aït Brahim, M. El Azzouzi, R.C. Maury, H. Bellon, B. Semroud, and E. laville,"Le poinçon maghrébin: contraintes structurales et géochimiques", C.R. Acad. Sci., vol. 326, pp. 575$581,1998$.
[39] A. Boudiaf, J.-F. Ritz, and H. Philip,"Drainage diversions as evidence of propagating active faults: example of the El Asnam and Thenia faults, Algeria", Terra Nova, vol. 10, pp. 236-244, 1998.

(C) Aifa and Idres; Licensee Bentham Open.

This is an open access article licensed under the terms of the Creative Commons Attribution Non-Commercial License (http://creativecommons.org/licenses/by-nc/ 3.0/) which permits unrestricted, non-commercial use, distribution and reproduction in any medium, provided the work is properly cited 